\title{
Randomized controlled clinical trial of ketoanalogues supplementation in dogs with chronic kidney disease ${ }^{1}$
}

\author{
Tácia T.A. Liguori ${ }^{2 *}$, Alessandra Melchert ${ }^{2}$, Regina K. Takahira ${ }^{2}$, Paulo R.R. Ramos ${ }^{3}$, \\ Carlos R. Padovani ${ }^{3}$, Pasqual Barretti ${ }^{4}$ and Priscylla T.C. Guimarães-Okamoto ${ }^{2}$
}

\begin{abstract}
Liguori T.T.A., Melchert A., Takahira R.K., Ramos P.R.R., Padovani C.R., Barreti P. \& Guimarães-Okamoto P.T.C. 2018. Randomized controlled clinical trial of ketoanalogues supplementation in dogs with chronic kidney disease. Pesquisa Veterinária Brasileira 38(3):489-495. Departamento de Clínica Veterinária, Faculdade de Medicina Veterinária e Zootecncia, Universidade Estadual Paulista, Av. Bento Lopes 679, Distrito Rubião Júnior, Botucatu, SP 18618-970, Brazil. E-mail: tacia.liguori@usp.br

The objective was to verify the effectiveness of ketoanalogues in dogs with Chronic Kidney Disease (CKD) stage 3. Controlled randomized clinical trial was performed with twenty dogs with CKD stage 3. Animals were subjected to: Group 1 (control): conventional therapy (CT) for CKD; Group 2: CT and 60mg/kg, OA, q48h of keto-supplement"; Group 3, $\mathrm{CT}$ and $60 \mathrm{mg} / \mathrm{kg}$, OA, q24h of keto-supplement ; and Group 4, CT and $120 \mathrm{mg} / \mathrm{kg}, \mathrm{OA}, \mathrm{q} 12 \mathrm{~h}$ of keto-supplement ${ }^{\mathrm{a}}$. All dogs received canine renal diet. Animals were evaluated at the beginning of therapy and after 15 and 30 days. Complete blood count (CBC), serum urea, creatinine, phosphorus, calcium, potassium and sodium and urine protein/creatinine (UPC) ratio were analyzed. The use of ketoanalogues in dogs with CKD stage 3 during the period of 30 days showed no efficacy, in any of the studies dosages, to improve signs and symptoms of the disease, improve the values of $\mathrm{CBC}$, reduce serum urea and creatinine, normalize electrolytes or reduce UPC. It is concluded that the use of ketoanalogues does not impact the clinical outcomes in dogs with CKD stage 3.
\end{abstract}

INDEX TERMS: Chronic kidney disease, dogs, essential amino acids, dietary supplements, clinics.

RESUMO.- [Estudo clínico randomizado controlado da suplementação de cetoanálogos em cães com doença renal crônica.] 0 objetivo foi de verificar a eficácia da suplementação com cetoanálogos em cães com Doença Renal Crônica (DRC) grau 3. Um ensaio clínico controlado e randomizado foi realizado com 20 cães com DRC grau 3. Os animais foram divididos em 4 grupos: grupo 1 (controle): terapia convencional (TC) para DRC; grupo 2: TC e $60 \mathrm{mg} / \mathrm{kg}$,

\footnotetext{
${ }^{1}$ Received on January 26, 2017.

Accepted for publication on July 21, 2017.

2 Departamento de Clínica Veterinária, Faculdade de Medicina Veterinária e Zootecnica (FMVZ), Universidade Estadual Paulista (Unesp), Av. Bento Lopes 679, Distrito Rubião Júnior, Botucatu, SP 18618-970, Brazil. *Corresponding author: tacia.liguori@usp.br

${ }^{3}$ Departamento de Bioestatística, Faculdade de Biociências, Universidade Estadual Paulista Unesp, Distrito Rubião Júnior, Botucatu, SP 18618-970, Brazil.

${ }^{4}$ Departamento de Medicina Interna, Faculdade de Medicina, Universidade Estadual Paulista Unesp, Distrito Rubião Júnior, Botucatu, SP 18618-970, Brazil.
}

V0, q48h de cetoanálogoa; grupo 3: TC e $60 \mathrm{mg} / \mathrm{kg}$, VO, q24h de cetoanálogoa; e grupo 4 , TC e $120 \mathrm{mg} / \mathrm{kg}$, VO, q12h de cetoanálogoa. Todos os cães receberam ração renal para cães. Os animais foram avaliados no início da terapia e após 15 e 30 dias. Hemograma completo, ureia, creatinina, fósforo, cálcio, potássio e sódio séricos e a razão proteína creatinina (RPC) urinária foram analisados. Foi verificado que o uso dos cetoanálogos em cães com DRC grau 3 durante 30 dias não mostrou eficácia, em nenhuma das dosagens utilizadas, em melhorar os sinais clínicos e sintomatologia da doença, os valores do hemograma e ureia e creatinina séricos, normalizar eletrólitos e reduzir RPC. Concluiu-se que o uso de cetoanálogos não impacta na melhora de sintomatologia clínica em cães com CKD grau 3. Como esse parece ser o primeiro ensaio clínico sobre cetoanálogos em cães com CKD, mais estudos podem ser necessários com maior acompanhamento e maiores grupos.

TERMOS DE INDEXAÇÃO: Cetoanálogos, cães, doença renal crônica, aminoácidos essenciais, suplementos alimentares, caninos, clínica. 


\section{INTRODUCTION}

Azotemic chronic kidney disease (CKD) is characterized by the progressive and irreversible loss of kidney function with decreased renal perfusion, glomerular filtration and capacity for concentrate urine (Pugliese et al. 2005). Among the functions that kidney fails to play are acid-base regulation, production of erythropoietin and vitamin $\mathrm{D}$, as well as control of blood pressure and creatinine, phosphorus, water and proteins levels. (Bartges 2012).

The main clinical signs of CKD are loss of appetite, lethargy, vomiting, weight loss, mouth ulcers, polyuria, polydipsia, dehydration, osteoarthritis and uremic encephalopathy (Polzin 2010). Conventional treatment consists of symptomatic support and appropriateness of acid-base, hidroelectrolyte, endocrine and nutritional balance (Roudebush et al. 2010).

An alternative to complement the conventional treatment is to supplement diet with ketoanalogues, a set of amino acids without the amino group, capable to capture serum nitrogen, becoming essential amino acids. Thus, it should reduce the amount of urea in the circulation and, therefore, renal overload. The currently most used option of keto-supplement (Ketosteril ${ }^{\circledR}$, Fresenius Kabi AG, Bad Homburg, Germany) is made up of precursors of essential amino acids such as leucine, isoleucine, phenylalanine, methionine, and valine, and calcium (Ulm et al. 1978, Kao et al. 2008).

Although a dose of ketoanalogues is suggested for dogs in literature ( 1 tablet of keto-supplement for each $5 \mathrm{~kg}$ of body weight every 12h) (Viana 2007) it has a very high cost, hindering the acceptance of treatment by the owners. Finding a lower effective dose would mean a greater number of owners capable to pay for the therapy. Besides the cost-effectiveness issue, to the authors' knowledge, until this date, no other study in literature was designed to investigate the effect of ketoanalogues in dogs with chronic kidney disease. Although one case report described the effectiveness of ketoanalogues when associated with a low protein diet (Veado et al. 2002), all the literature is focused in humans (Frohling et al. 1980, Jones et al. 1983, Mitch et al. 1984, Tóth et al. 2012, Teplan et al. 2000, Prakash et al. 2004, Thilly 2013).

The objective of this study was to evaluate the efficacy of ketoanalogues administration in both literature described dose and smaller dosages during the treatment of dogs with stage 3 chronic kidney disease.

\section{MATERIALS AND METHODS}

Ethics statement. Twenty dogs, of both sexes and various ages, routinely attended at a university veterinary teaching hospital were evaluated. The project was submitted to the Ethics Committee on Animal Use (CEUA) in the date of March 31, 2011, and was filed (no. 80/2011- CEUA).

Animals. Dogs with history, physical examination and laboratory tests (complete blood count, biochemical profile, urinary protein/ creatinine ratio (UPC), urinalysis and abdominal ultrasound) compatible with CKD were preselected. Following screening, animals were treated with conventional therapy, electrolytes and hydric replacement. After 15 days of treatment, animals that presented stable serum creatinine concentrations between
2.1-5.0mg/dL and systolic pressure between 160-179mmHg were classified as CKD stage 3 , as described by the International Society of interest and Renal European and American Society of Nephrology and Urology Veterinary (Polzin 2011), and were selected for this study.

Study design. Dogs were consecutively randomized into four experimental groups composed of five animals each one. Each group received a different treatment as described: Group 1 (control): conventional therapy (CT) for CKD; Group 2: CT and 60mg/kg (27mg/lb), OA, q 48h of keto-supplement (Ketosteril ${ }^{\circledR}$, Fresenius Kabi AG, Bad Homburg, Germany); Group 3, CT and 60mg/kg (27mg/lb), OA, q $24 \mathrm{~h}$ of keto-supplement; and Group 4, CT and $120 \mathrm{mg} / \mathrm{kg}$ [54mg/lb], OA, q 12h of keto-supplement (dosage described in literature) (Viana 2007). All animals were submitted to conventional therapy for CKD (intravenous fluid, emesis control and correction of anemia with ferrous sulfate $(100 \mathrm{mg} /$ day)) and fed with commercial feed for dogs with kidney disease (Royal Canin ${ }^{\circledR}$, Canine Veterinary Diet Renal RF 16; Royal Canin ${ }^{\circledR}$, Aimarques, France), according to the recommendations of the manufacturer. Animals presenting systemic arterial hypertension were treated with benazepril $(0.5 \mathrm{mg} / \mathrm{kg} /$ day $)$, and supplemented with intravenous potassium $(6 \mathrm{ml} / \mathrm{kg} / \mathrm{h})$ when necessary. No other treatment was used in the patients.

The evaluation of each animal was performed within a period of 30 days, during which, in addition to clinical evaluation, three laboratory assessments were performed, the first at the beginning of treatment, the second after 15 days and the third after 30 days.

Hematological parameters evaluated in this study were red blood count, hemoglobin, hematocrit, total protein, platelets and leukocytes. Biochemical profile was used to determine the concentrations of serum urea, creatinine, phosphorus, calcium, potassium, and sodium. Finally, urinalysis was performed and urinary protein/creatinine (UPC) ratio was calculated.

Statistics. Results are expressed as mean \pm SEM. Data were assessed by 1-way ANOVA for comparisons within groups followed by post hoc Bonferroni's test. Two-way ANOVA was used for comparisons between groups, followed by post hoc Bonferroni's test. To evaluate the association between qualitative variables Fisher's exact test was used. Data were analyzed using SigmaPlot for Windows Version 11.0 (Systat Software Inc., Chicago, USA). Statistical significance was accepted at a value of $\mathrm{P}=0.05$.

\section{RESULTS}

The sample consisted of 13 females (65\%) and 7 males (35\%) of different ages and breeds. The comparison of the characteristics and parameters of the four groups at the beginning of the study is shown in Table 1 and demonstrates no significant differences among them.

Systolic blood pressure of all the dogs was also assessed at the beginning of the study, so that the value of Groups 1, 2, 3 and 4 was, respectively, $152 \pm 18 \mathrm{mmHg}$, $185 \pm 56 \mathrm{mmHg}, 169 \pm 36 \mathrm{mmHg}$ and $178 \pm 4 \mathrm{mmHg}$, with no statistical significant difference between the groups (One-way ANOVA; $\mathrm{P}=0.684$ ).

The signs and symptoms exhibited by the dogs were analyzed 15 days after the beginning of treatment and are summarized in Figure 1. There was no statistically significant difference between the amount of signs and symptoms shown by dogs of the four groups (Fischer's exact test; $\mathrm{P}=0.502$ ), although a greater number of asymptomatic dogs was observed in Group 3. 
Table 1. Characteristics and parameters of the four groups at beginning of the study

\begin{tabular}{|c|c|c|c|c|c|c|}
\hline & & Group 1 & Group 2 & Group 3 & Group 4 & P-value \\
\hline \multirow{5}{*}{$\begin{array}{l}\text { Complete } \\
\text { Blood Count }\end{array}$} & Hemoglobin & $10.8 \pm 1.4$ & $8.3 \pm 3.5$ & $10.1 \pm 3.7$ & $7.7 \pm 1.8$ & 0.344 \\
\hline & Red Blood Cells & $3.4^{*} 10^{6} \pm 0.6^{*} 10^{6}$ & $3.0^{*} 10^{6} \pm 1.1^{*} 10^{6}$ & $3.8^{*} 10^{6} \pm 1.4^{*} 10^{6}$ & $3.0^{*} 10^{6} \pm 0.6^{*} 10^{6}$ & 0.560 \\
\hline & Platelet & $318.250 \pm 128.334$ & $283.000 \pm 115.022$ & $235.725 \pm 150.721$ & $298.590 \pm 122.077$ & 0.795 \\
\hline & Leukocytes & $8.840 \pm 1.734$ & $6.744 \pm 927$ & $8620 \pm 2310$ & $15.893 \pm 10.507$ & 0.080 \\
\hline & Total Protein & $8.1 \pm 1.3$ & $6.7 \pm 0.6$ & $8.0 \pm 0.9$ & $7.3 \pm 0.9$ & 0.197 \\
\hline \multirow{5}{*}{$\begin{array}{l}\text { Biochemical } \\
\text { Profile }\end{array}$} & Creatinine & $3.2 \pm 0.5$ & $3.0 \pm 0.6$ & $3.1 \pm 0.9$ & $3.3 \pm 1.0$ & 0.894 \\
\hline & Calcium & $11.1 \pm 2.9$ & $11.1 \pm 1.0$ & $9.6 \pm 1.7$ & $11.0 \pm 1.1$ & 0.366 \\
\hline & Phosphorus & $6.6 \pm 1.3$ & $8.6 \pm 4.5$ & $8.7 \pm 2.6$ & $8.1 \pm 1.9$ & 0.612 \\
\hline & Potassium & $5.0 \pm 1.5$ & $6.2 \pm 0.7$ & $4.7 \pm 1.9$ & $6.8 \pm 0.7$ & 0.250 \\
\hline & Sodium & $162.0 \pm 25.4$ & $155.8 \pm 15.9$ & $148.7 \pm 1.5$ & $150.5 \pm 7.0$ & 0.680 \\
\hline
\end{tabular}

Characteristics and parameters of the four groups at the beginning of the study. Group 1 (control) = CT for CKD, Group $2=\mathrm{CT}$ and $60 \mathrm{mg} / \mathrm{kg}$ [27mg/lb], PO, q 48h of keto-supplement ${ }^{\mathrm{a}}$, Group $3=\mathrm{CT}$ and $60 \mathrm{mg} / \mathrm{kg}$ [27mg/lb], PO, q $24 \mathrm{~h}$ of keto-supplement ${ }^{\mathrm{a}}$, Group $4=\mathrm{CT}$ and $120 \mathrm{mg} / \mathrm{kg}$ [54mg/lb], PO, q $12 \mathrm{~h}$ of keto-supplement ${ }^{\text {a. }}$ P-value of one-way ANOVA analysis.

\begin{tabular}{|c|c|c|c|c|c|c|c|c|c|c|c|c|c|c|c|c|c|c|c|c|c|}
\hline \multirow[b]{2}{*}{ SYMPTOM } & \multicolumn{5}{|c|}{ GROUP 1} & \multicolumn{5}{|c|}{ GROUP2 } & \multicolumn{5}{|c|}{ GROUP3 } & \multicolumn{5}{|c|}{ GROUP4 } & \multirow[b]{2}{*}{ TOTAL } \\
\hline & 1 & 2 & 3 & 4 & 5 & 6 & 7 & 8 & 9 & 10 & 11 & 12 & 13 & 14 & 15 & 16 & 17 & 18 & 19 & 20 & \\
\hline DECREASED APPETITE & & & & & & & & & & & & & & & & & & & & & 9 \\
\hline APATHY & & & & & & & & & & & & & & & & & & & & & 7 \\
\hline POLYDIPSIA & & & & & & & & & & & & & & & & & & & & & 7 \\
\hline POLYURIA & & & & & & & & & & & & & & & & & & & & & 5 \\
\hline DIARRHEA & & & & & & & & & & & & & & & & & & & & & 5 \\
\hline EMESIS & & & & & & & & & & & & & & & & & & & & & 4 \\
\hline WEIGHT LOSS & & & & & & & & & & & & & & & & & & & & & 3 \\
\hline ABDOMINAL PAIN & & & & & & & & & & & & & & & & & & & & & 1 \\
\hline MUSCLE FASCICULATIONS & & & & & & & & & & & & & & & & & & & & & 1 \\
\hline CONVULSION & & & & & & & & & & & & & & & & & & & & & 1 \\
\hline TOTAL & 2 & 1 & 0 & 2 & 5 & 0 & 3 & 1 & 3 & 1 & 5 & 0 & 0 & 0 & 4 & 1 & 5 & 3 & 4 & 3 & 43 \\
\hline
\end{tabular}

Fig.1. Comparison of clinical signs and symptoms between the groups 15 days after the beginning of treatment. Group 1

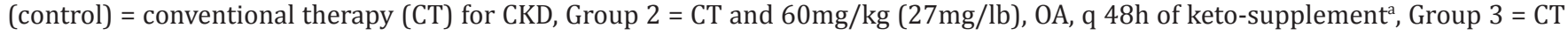
and $60 \mathrm{mg} / \mathrm{kg}$ (27mg/lb), OA, q $24 \mathrm{~h}$ of keto-supplement ${ }^{\mathrm{a}}$, Group 4 = CT and 120mg/kg [54mg/lb], OA, q 12h of keto-supplement .

Complete blood count results were summarized in Figure 2. Statistical analysis showed no significant difference in the values of red blood count, hemoglobin, hematocrit and leukocytes. Platelets values, however, showed statistical significant difference of 303,850 platelets/dL (95\% CI 166,247-441,452; $\mathrm{P}=0.006)$ in Group 4, after 30 days, being higher when compared to the control group.

Biochemical profile results were summarized in Figure 3. Statistical analysis showed no significant difference in the values of urea, phosphorus, calcium, potassium and sodium. Creatinine values, in this case, were $4.45 \mathrm{mg} / \mathrm{dL}$ (95\% CI 0.38-8.52; $\mathrm{P}=0.001$ ) higher in Group 4, after 30 days, when compared to the control group, being the only statistical significant difference among the groups in regard to the biochemical profile.

Finally, UPC results were summarized in Figure 4. Statistic difference was found among the groups (Two-way ANOVA; $\mathrm{P}=0.044$ ), however no group could be isolated after Bonferroni's post hoc test. 

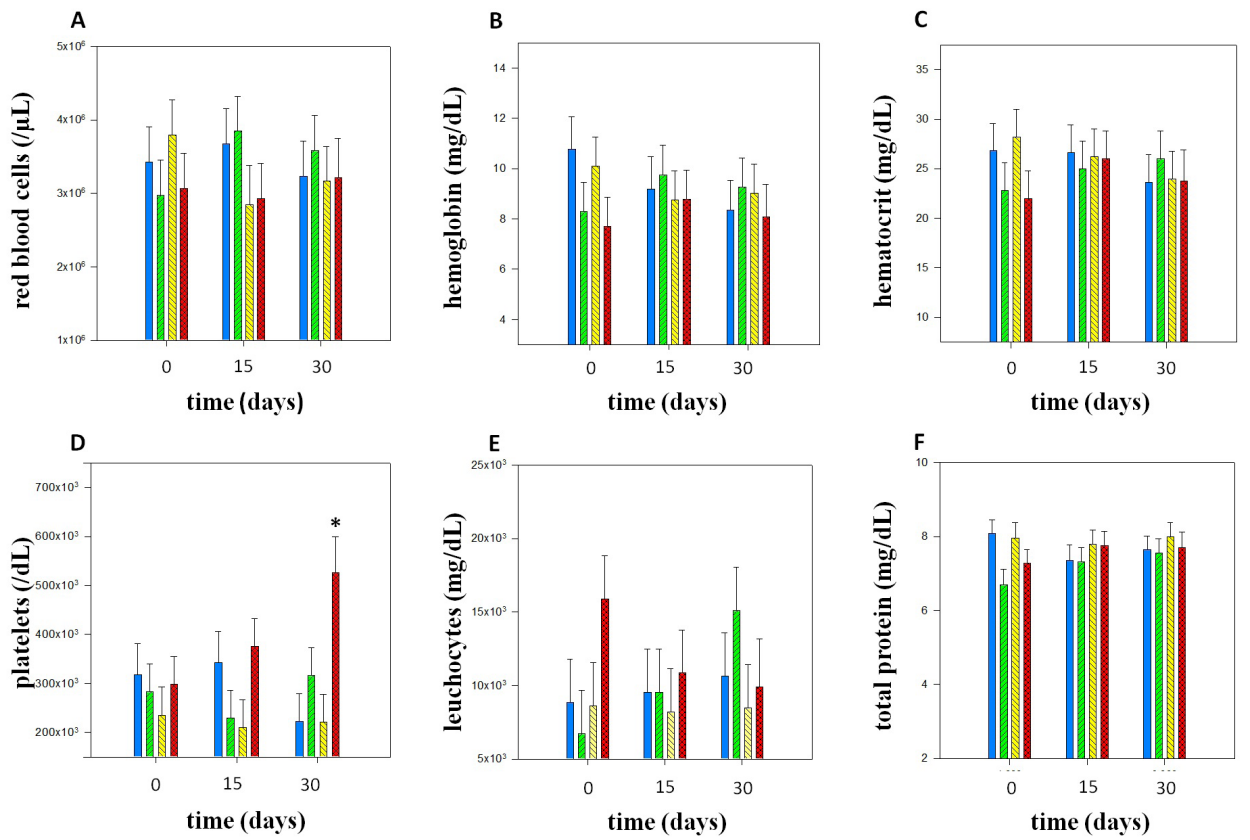

Fig.2. Blue bar, Group 1 control (CT for CKD); green bar, Group 2 (CT and 60mg/kg (27mg/lb), OA, q 48h of keto-supplement ${ }^{\mathrm{a}}$ ); yellow bar, Group 3 (CT and 60mg/kg (27mg/lb), OA, q 24h of keto-supplementa); red bar, Group 4 (CT and 120mg/kg (54mg/lb), OA, q 12h of keto-supplement ${ }^{\mathrm{a}}$ ). 0, day before the beginning of treatment; 15, 15 days after the beginning of treatment; 30, 30 days after beginning of treatment. (A) Red blood cells count. P=NS between groups and control by 2-way ANOVA. (B) Hemoglobin. P=NS between groups and control by 2-way ANOVA. (C) Hematocrit. P=NS between groups and control by 2-way ANOVA. (D) Platelets. *P=0.006 vs. control, 2-way ANOVA, Bonferroni post hoc test. (E) Leucocytes. P=NS between groups and control by 2-way ANOVA. (F) Total Protein. P=NS between groups and control by 2-way ANOVA.
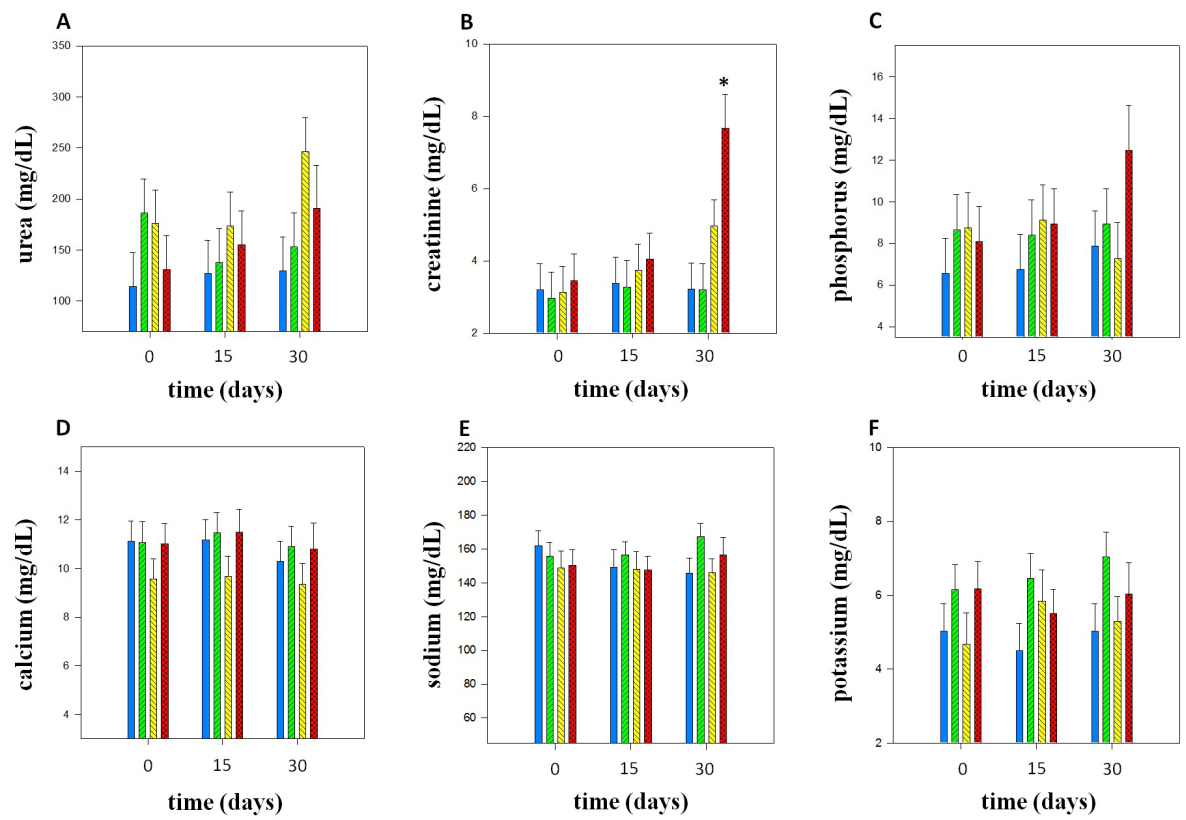

Fig.3. Blue bar, Group 1 control (CT for CKD); green bar, Group 2 (CT and 60mg/kg (27mg/lb), OA, q 48h of keto-supplement ${ }^{\mathrm{a}}$ ); yellow bar, Group 3 (CT and 60mg/kg (27mg/lb), OA, q 24h of keto-supplement ${ }^{\mathrm{a}}$ ); red bar, Group 4 (CT and 120mg/kg (54mg/lb), OA, q 12h of keto-supplement ${ }^{\mathrm{a}}$ ). 0, day before the beginning of treatment; 15, 15 days after the beginning of treatment; 30, 30 days after beginning of treatment. A, Urea. $\mathrm{P}=\mathrm{NS}$ between groups and control by 2 -way ANOVA. B, Creatinine. * $\mathrm{P}=0.001$ vs. control, 2-way ANOVA, Bonferroni post hoc test. C, Phosphorus. $\mathrm{P}=\mathrm{NS}$ between groups and control by 2-way ANOVA. D, Calcium. P=NS between groups and control by 2-way ANOVA. E, Sodium. P=NS between groups and control by 2-way ANOVA. F, Potassium. P=NS between groups and control by 2-way ANOVA. 


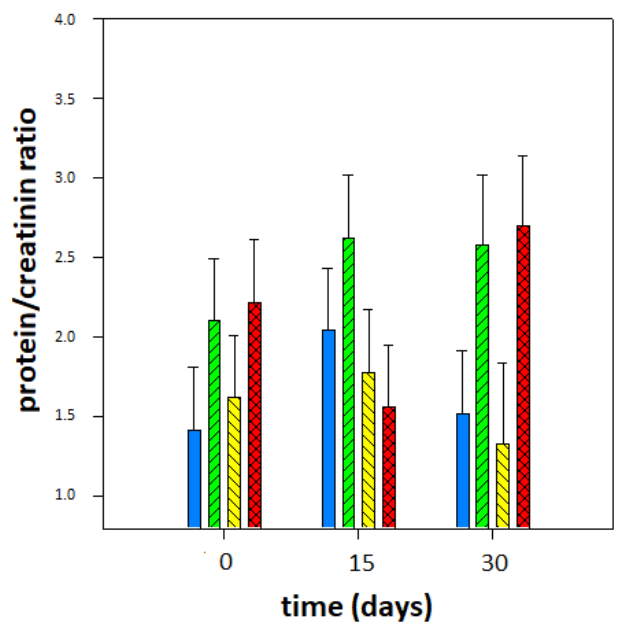

Fig.4. Blue bar, Group 1 control (CT for CKD); green bar, Group 2 (CT and $60 \mathrm{mg} / \mathrm{kg}(27 \mathrm{mg} / \mathrm{lb}), \mathrm{OA}, \mathrm{q} 48 \mathrm{~h}$ of keto-supplement ${ }^{\mathrm{a}}$; yellow bar, Group 3 (CT and 60mg/kg (27mg/lb), OA, q $24 \mathrm{~h}$ of keto-supplement ${ }^{\mathrm{a}}$ ); red bar, Group 4 (CT and $120 \mathrm{mg} / \mathrm{kg}$ $(54 \mathrm{mg} / \mathrm{lb}), 0 A, \mathrm{q} 12 \mathrm{~h}$ of keto-supplement $\left.\mathrm{t}^{\mathrm{a}}\right)$. 0 , day before the beginning of treatment; 15, 15 days after the beginning of treatment; 30, 30 days after beginning of treatment. Urinary Protein/Creatinin Ratio (UPC). Statistic difference was found among the groups (Two-way ANOVA; $\mathrm{P}=0.044$ ), however no group could be isolated after Bonferroni's post hoc test.

\section{DISCUSSION}

The clinical manifestations most commonly found in dogs with CKD are those caused by the involvement of the digestive system, including decreased appetite (appetite loss/anorexia), modification of the consistency and color of stools, vomiting and weight loss, most of them being related to the increased uremic toxins in the circulation (Notomi et al. 2006). These observations corroborate with the findings of the present study, which further adds to this set of gastrointestinal symptoms abdominal pain. The literature also describes other findings in animals with CKD, as halitosis, ulcers and stomatitis (Bartges 2012). Our casuistic also showed apathy, polydipsia, polyuria, muscle fasciculation and convulsing as signs and symptoms worthy of note. A limitation of the present study was the fact that data regarding signs and symptoms were collected at only one timepoint during the follow-up period, not allowing to trace their progression over time.

In respect to the findings in the complete blood count, our study shows compatible results with the literature, according to which dogs with CKD have hemoglobin, hematocrit and red blood cells below the reference values for healthy animals (Bueno de Camargo et al. 2006). The presence of lymphopenia is a finding in both humans (Allon et al. 2003) and dogs (Bradea et al. 2013) with CKD, which reinforces the fact that secondary infections are among the most common complications of the disease. It was also described that the more significant is the decrease in leukocyte count, the worse are clinical signs and azotemia (Kralova et al. 2010). Humans with terminal stage of chronic kidney disease usually present platelet dysfunction due to uremia and platelet values decrease over time, leading to bleeding (Kaw \& Malhotra 2006). The mechanism involved in the lymphopenia in these patients is related with an impaired elimination and also a misbalance between pro-inflammatory cytokines, as Il- 6 and TNF-alfa (Pecoits-Filho et al. 2003), and anti-inflammatory cytokines, as IL-10 (Stenvinkel et al. 2005).

In our study, however, although Group 4 presented an increase in platelets value, it is probably not correlated with improvement of the disease, since other more representative parameters, such as urea, creatinine and UPC continued to increase.

Regarding urea and creatinine, the ingestion of ketoanalogues together with a low protein diet content showed improvement in glomerular filtration rate, which may have promoted the maintenance of energetic balance and reduction of clinical signs of uremia in human adults (ETESA 2002, Prakash et al. 2004, Chang et al. 2009, Garneata \& Mircescu 2013). However, a study in children showed no significant difference in glomerular filtration, but was effective to increase body cell mass as well as decrease the fraction of urea/creatinine in all children studied (Jones et al. 1983).

In a veterinary case report, it was shown that a low protein diet with the keto-supplement nutraceutical, in a dosage of 1 tablet to every $5 \mathrm{~kg}$ of weight per day, was responsible for decreasing the serum concentration of urea in a dog with acute renal failure treated for leishmaniosis (Veado et al. 2002). In another human research, it was showed that a vegetable proteins diet supplemented with keto-supplement decreased serum urea (Garneata \& Mircescu 2013, Mircescu et al. 2007). In the present study, however, no statistically significant difference in the values of urea between groups under different therapeutic doses of ketoanalogues were found. In our study, supplementation with ketanalogues did not decrease serum creatinine, in fact there was a statistically significant increase in Group 4 after 30 days. One of the possible reasons for that is that creatinine metabolism may suffer influence of age, loss of muscle mass, diet, trauma and fever (Braun et al. 2003, Levey et al. 1988). Thus, this isolated finding could not suggest a negative effect of ketoanalogues, but might reinforce the other findings showing no efficacy of the nutraceutical to improve chronic kidney disease.

A secondary effect of the CKD is hyperparathyroidism, related to kidney inability to excrete phosphorus and the consequent mobilization of bone calcium. In a case report, a dog with facial distortion and tooth mobility presented blood exams showing urea $185 \mathrm{mg} / \mathrm{dL}$, creatinine $4.6 \mathrm{mg} / \mathrm{dL}$, and phosphorus $16 \mathrm{mg} / \mathrm{dL}$, confirming hyperparathyroidism secondary to CKD (Castro et al. 2007). According to literature data, the prevalence of secondary hyperparathyroidism seems to increase as higher the stage of CKD (Cortadellas et al. 2010). Thus, it is important to maintain the serum phosphorus in certain values that vary according to the stage of disease, with 3.5-5.0mg/dL in CKD stage 3 (Cortadellas et al. 2010, Polzin 2013). Also, the prescription of a low protein diet has been suggested as a way to improve phosphorus/calcium rate in a study conducted in humans (Mitch 2005, Malvy et al. 1999). In the present study, however, the therapy with ketoanalogues and food for dogs with chronic kidney disease was not able to maintain the values of phosphorus and calcium in the recommended value.

Dogs with chronic kidney disease may have depletion in potassium. That could be due to hyporexia or because of potassium elimination in the urine (Fascetti 2015). The same does not occur with sodium, which is usually normal. In the 
event of sodium retention, this might be due to intravascular volume contraction and thus has to be controlled to avoid hypertension (Bartges 2012). Thereto, one study demonstrated that both renal diet or a diet with low potassium were able to normalize the serum potassium levels (Segev et al. 2010). In our study, however, serum potassium values remained high in all groups except by the control, although no statistic difference was find between the therapeutic groups and the control. Regarding sodium, our study showed that serum values varied within and among the groups, most of the time above the reference values, but without any statistic difference between the groups.

One of the most known ways used for quantification of proteinuria in animals and humans is through the measurement of urinary protein/creatine ratio (UPC). It is considered as an important marker of progression of kidney disease (Methven et al. 2010, Grauer 2013) and is also an inexpensive predictor of the glomerular filtration rate (Ruggenenti et al. 1998). A human study with 6 months of follow up showed that the administration of 12 tablets of keto-supplement ${ }^{\text {a }}$, per day, with a low protein diet was efficient in decreased glomerular filtration rate (Chang et al. 2009). Another study with humans showed that a low-protein diet associated with supplementation ketoanalogues was effective in delaying progression of the disease (Tzekov et al. 2000). However, a third study showed that humans treated with a protein restrict diet supplemented with keto and hydroxy analogues of amino acids $(0.17 \mathrm{~g} / \mathrm{kg} /$ day $)$ did not present improvement of the renal function (Malvy et al. 1999). During the time that the animals were assessed in our study, no differences in the UPC values could be found between the therapeutic groups and the control.

\section{CONCLUSIONS}

The use of ketoanalogues in dogs with CKD stage 3 during a 30-day follow-up period, in dosages described in literature and lower, showed no efficacy to improve the signs and symptoms of the disease, raise the values of hemoglobin, hematocrit and red blood cells, total protein, leukocytes, platelets, reduce serum urea and creatinine values, normalize electrolytes (phosphorus, calcium, potassium and sodium) or reduce UPC.

To our knowledge, this is the first study that compares the effect of different dosages of ketoanalogues in dogs with chronic kidney disease. Thus, further studies are needed, with longer segment and larger samples, to better understand the effects of ketoanalogues in dogs with CKD.

Acknowledgements.- The first author received scholarship from the São Paulo Research Foundation (FAPESP; grant number 11/18569-4) for two years (2011-2012) to develop this research.

\section{REFERENCES}

Allon M., Depner T.A., Radeva M., Bailey J., Beddhu S., Butterly D., Coyne D.W., Gassman J.J., Kaufman A.M., Kaysen G.A., Lewis J.A., Schwab S.J. \& Group H.S. 2003. Impact of dialysis dose and membrane on infection-related hospitalization and death: results of the HEMO Study. J. Am. Soc. Nephrol. 14(7):1863-1870. http://dx.doi.org/10.1097/01.ASN.0000074237.78764. D1. PMid:12819247.
Bartges J.W. 2012. Chronic kidney disease in dogs and cats. Vet. Clin. N. Am., Small Anim. Pract. 42(4):669-692. http://dx.doi.org/10.1016/j. cvsm.2012.04.008. PMid:22720808.

Bradea A., Codreanu M., Vlagioiu C. \& Simion V. 2013. Hematologic aspects in chronic kidney disease (CDK) in dogs. Bull. UASVM. Vet. Med. 70:191-194.

Braun J.P., Lefebvre H.P. \& Watson A.D. 2003. Creatinine in the dog: a review. Vet. Clin. Pathol. 32(4):162-179. http://dx.doi.org/10.1111/j.1939165X.2003.tb00332.x. PMid:14655101.

Bueno de Camargo M.H., Moraes J.R.E., Carvalho M.B., Ferraro G.C. \& Palmeira Borges V. 2006. Alterações morfológicas e funcionais dos rins de cães com insuficiência renal crônica. Arq. Bras. Med. Vet. Zootec. 58(5):781-787. http://dx.doi.org/10.1590/S0102-09352006000500013.

Castro M.C.N., Mendes-de-Almeida F., Ferreira A.M.R., Dos Santos Salomão M.C. \& Paes-de-Almeida E.C. 2007. Hiperparatireoidismo renal secundário em cão jovem. Acta Sci. Vet. 35:s577-s578.

Chang J.H., Kim D.K., Park J.T., Kang E.W., Yoo T.H., Kim B.S., Choi K.H., Lee H.Y., Han D.S. \& Shin S.K. 2009. Influence of ketoanalogs supplementation on the progression in chronic kidney disease patients who had training on low-protein diet. Nephrology, Carlton, 14(8):750-757. http://dx.doi. org/10.1111/j.1440-1797.2009.01115.x. PMid:20025684.

Cortadellas O., Palacio M.J.F., Talavera J. \& Bayón A. 2010. Calcium and phosphorus homeostasis in dogs with spontaneous chronic kidney disease at different stages of severity. J. Vet. Intern. Med. 24(1):73-79. http://dx.doi. org/10.1111/j.1939-1676.2009.0415.x. PMid:19925576.

ETESA 2002. Efectividad del Ketosteril para retardar el inicio de la diálisis en pacientes con insuficiencia renal crónica. Unidad de Evaluación de Tecnologías de Salud, Departamento de Calidad en la Red, División de Planificación Estratégica, Ministerio de Salud. Biblioteca de Salud Dr. Bogoslav Juricic Turina, Santiago de Chile, Chile.

Fascetti A.J. 2015. Nutritional Management of Chronic Renal Disease [Online]. UC Davis Veterinary Medicine. Available at <http://www. vetmed.ucdavis.edu/vmth/small_animal/nutrition/client_info_sheets/ chronic_renal_disease.cfm>

Frohling P.T., Schmicker R., Vetter K., Kaschube I., Gotz K.H., Jacopian M. \& Klinkman H. 1980. Conservative treatment with ketoacid and amino acid supplemented low-protein diets in chronic renal failure. Am. J. Clin. Nutr. 33(7):1667-1672. http://dx.doi.org/10.1093/ajcn/33.7.1667. PMid:7395787.

Garneata L. \& Mircescu G. 2013. Effect of low-protein diet supplemented with keto acids on progression of chronic kidney disease. J. Ren. Nutr. 23(3):210213. http://dx.doi.org/10.1053/j.jrn.2013.01.030. PMid:23611549.

Grauer G.F. 2013. Measurement and interpretation of proteinuria and albuminuria (Online). International Renal Interest Society. Available at $<$ http://www.iris-kidney.com/education/proteinuria.shtml>

Jones R., Dalton N., Turner C., Start K., Haycock G. \& Chantler C. 1983. Oral essential aminoacid and ketoacid supplements in children with chronic renal failure. Kidney Int. 24(1):95-103. http://dx.doi.org/10.1038/ ki.1983.130. PMid:6620854.

Kao T.W., Liao C.T., Shiao C.C., Kuo Y.H., Hung K.Y. \& Wu K.D. 2008. Low protein diet supplemented with ketoanalogues makes hemodialysis withdrawal possible. Am. J. Kidney Dis. 51(1):160-161. http://dx.doi.org/10.1053/j. ajkd.2007.10.033. PMid:18155546.

Kaw D. \& Malhotra D. 2006. Platelet dysfunction and end-stage renal disease. Semin. Dial. 19(4):317-322. http://dx.doi.org/10.1111/j.1525139X.2006.00179.x. PMid:16893410.

Kralova S., Leva L. \& Toman M. 2010. Changes in lymphocyte function and subsets in dogs with naturally occurring chronic renal failure. Can. J. Vet. Res. 74(2):124-129. PMid:20592842.

Levey A.S., Perrone R.D. \& Madias N.E. 1988. Serum creatinine and renal function. Annu. Rev. Med. 39(1):465-490. http://dx.doi.org/10.1146/ annurev.me.39.020188.002341. PMid:3285786. 
Malvy D., Maingourd C., Pengloan J., Bagros P. \& Nivet H. 1999. Effects of severe protein restriction with ketoanalogues in advanced renal failure. J. Am. Coll. Nutr. 18(5):481-486. http://dx.doi.org/10.1080/07315724.1 999.10718887. PMid:10511331.

Methven S., Macgregor M.S., Traynor J.P., O'reilly D.S. \& Deighan C.J. 2010. Assessing proteinuria in chronic kidney disease: protein-creatinine ratio versus albumin-creatinine ratio. Nephrol. Dial. Transplant. 25(9):29912996. http://dx.doi.org/10.1093/ndt/gfq140. PMid:20237054.

Mircescu G., Garneata L., Stancu S.H. \& Capusa C. 2007. Effects of a supplemented hypoproteic diet in chronic kidney disease. J. Ren. Nutr. 17(3):179-188. http://dx.doi.org/10.1053/j.jrn.2006.12.012. PMid:17462550.

Mitch W.E. 2005. Beneficial responses to modified diets in treating patients with chronic kidney disease. Kidney Int. Suppl. 67(94):S133-S135. http:// dx.doi.org/10.1111/j.1523-1755.2005.09430.x. PMid:15752230.

Mitch W.E., Walser M., Steinman T.I., Hill S., Zeger S. \& Tungsanga K. 1984. The effect of a keto acid-amino acid supplement to a restricted diet on the progression of chronic renal failure. N. Engl. J. Med. 311(10):623-629. http://dx.doi.org/10.1056/NEJM198409063111002. PMid:6472341.

Notomi M.K., Kogika M.M., Ikesaki J.Y.H., Monteiro P. \& Marquesi M. 2006. Estudo retrospectivo de casos de insuficiência renal crônica em cães no período de 1999 a 2002. Braz. J. Vet. Res. Anim. Sci. 43(Supl.):12-22. http:// dx.doi.org/10.11606/issn.1678-4456.bjvras.2006.26530.

Pecoits-Filho R., Heimbürger O., Bárány P., Suliman M., Fehrman-Ekholm I., Lindholm B. \& Stenvinkel P. 2003. Associations between circulating inflammatory markers and residual renal function in CRF patients. Am. J. Kidney Dis. 41(6):1212-1218. http://dx.doi.org/10.1016/S02726386(03)00353-6. PMid:12776273.

Polzin D. 2010. Chronic kidney disease, p.2036-2067. In: Ettinger S. \& Feldman E. (Eds), Textbook of Veterinary Internal Medicine. Saunders Elsevier, St Louis.

Polzin D.J. 2011. Chronic kidney disease in small animals. Vet. Clin. North Am. Small Anim. Pract. 41(1):15-30. http://dx.doi.org/10.1016/j. cvsm.2010.09.004. PMid:21251509.

Polzin D.J. 2013. Evidence-based step-wise approach to managing chronic kidney disease in dogs and cats. J. Vet. Emerg. Crit. Care 23(2):205-215. http://dx.doi.org/10.1111/vec.12034. PMid:23470210.

Prakash S., Pande D.P., Sharma S., Sharma D., Bal C.S. \& Kulkarni H. 2004. Randomized, double-blind, placebo-controlled trial to evaluate efficacy of ketodiet in predialytic chronic renal failure. J. Ren. Nutr. 14(2):89-96. http://dx.doi.org/10.1053/j.jrn.2004.01.008. PMid:15060873.

Pugliese A., Gruppillo A. \& Di Pietro S. 2005. Clinical nutrition in gerontology: chronic renal disorders of the dog and cat. Vet. Res. Commun. 29(Suppl.2):57-63. http://dx.doi.org/10.1007/s11259-005-0012-6. PMid:16244926.
Roudebush P., Polzin D.J., Adams L.G., Towell T.L. \& Forrester S.D. 2010. An evidence-based review of therapies for canine chronic kidney disease. J. Small Anim. Pract. 51(5):244-252. http://dx.doi.org/10.1111/j.17485827.2010.00932.x. PMid:20402842.

Ruggenenti P., Gaspari F., Perna A. \& Remuzzi G. 1998. Cross sectional longitudinal study of spot morning urine protein:creatinine ratio, 24 hour urine protein excretion rate, glomerular filtration rate, and end stage renal failure in chronic renal disease in patients without diabetes. BMJ 316(7130):504-509. http://dx.doi.org/10.1136/bmj.316.7130.504. PMid:9501711.

Segev G., Fascetti A.J., Weeth L.P. \& Cowgill L.D. 2010. Correction of hyperkalemia in dogs with chronic kidney disease consuming commercial renal therapeutic diets by a potassium-reduced home-prepared diet. J. Vet. Intern. Med. 24(3):546-550. http://dx.doi.org/10.1111/j.1939-1676.2010.0488.x. PMid:20337915.

Stenvinkel P., Ketteler M., Johnson R.J., Lindholm B., Pecoits-Filho R., Riella M., Heimbürger O., Cederholm T. \& Girndt M. 2005. IL-10, IL-6, and TNFalpha: central factors in the altered cytokine network of uremia, the good, the bad, and the ugly. Kidney Int. 67(4):1216-1233. http://dx.doi. org/10.1111/j.1523-1755.2005.00200.x. PMid:15780075.

Teplan V., Schuck O., Horackova M., Skibova J. \& Holecek M. 2000. Effect of a keto acid-amino acid supplement on the metabolism and renal elimination of branched-chain amino acids in patients with chronic renal insufficiency on a low protein diet. Wien. Klin. Wochenschr. 112(20):876881. PMid:11244613.

Thilly N. 2013. Low-protein diet in chronic kidney disease: from questions of effectiveness to those of feasibility. Nephrol. Dial. Transplant. 28(9):22032205. http://dx.doi.org/10.1093/ndt/gft235. PMid:23787548.

Tóth E., Bacskai M., Nagy B. \& Lang Z. 2012. PUK16 Cost-effectiveness of ketosteril treatment in stage 3-4 CKD patients. Value Health 15(7):A458. http://dx.doi.org/10.1016/j.jval.2012.08.1454.

Tzekov V.D., Tilkian E.E., Pandeva S.M., Nikolov D.G., Kumchev E.P., Manev E.I. \& Dimitrakov D.J. 2000. Low protein diet and ketosteril in predialysis patients with renal failure. Folia Med., Plovdiv, 42(2):34-37. PMid:11217281.

Ulm A., Neuhäuser M. \& Leber H.W. 1978. Influence of essential amino acids and keto acids on protein metabolism and anemia of patients on intermittent hemodialysis. Am. J. Clin. Nutr. 31(10):1827-1830. http:// dx.doi.org/10.1093/ajen/31.10.1827. PMid:707339.

Veado J.C.C., Oliveira J., Menezes J.M.C. \& Guimarães P.T.C. 2002. Uso de cetoanálogo na terapia da insuficiência renal canina. Arq. Bras. Med. Vet. Zootec. 54(5):543-545. http://dx.doi.org/10.1590/S0102-09352002000500015.

Viana F. 2007. Guia Terapêutico Veterinário. Gráfica e Editora Cem Ltda, Lagoa Santa, MG. 